\title{
X-Linked Dystonia Parkinsonism
}

National Cancer Institute

\section{Source}

National Cancer Institute. X-Linked Dystonia Parkinsonism. NCI Thesaurus. Code C126330.

An X-linked recessive inherited movement disorder caused by mutations in and near the TAF1 gene. It is found only in people of Filipino descent. It is characterized by parkinsonism and later in life the development of involuntary, sustained muscle contractions. 